\title{
Psychosocial Aspect of Psychiatric Disorders
}

\section{Psikiyatrik Bozuklukların Psikososyal Yönü}

\author{
Müne Aktay ${ }^{1}$, Gökben Hızlı Sayar ${ }^{1}$
}

\begin{abstract}
:
Psychiatric disorders arise as a result of a combination of biological, genetic, psychological, and environmental factors and their mutual interaction. It is important to determine and evaluation of the factors that affect the formation of diseases in terms of treatment. Stressful life events, childhood traumas, family problems, conflicts, and losses are important psychosocial factors that have an impact on the onset of mental illness. In this study, psychosocial factors that play an important role in the emergence of psychiatric disorders are examined. By making the definitions of psychiatric disorders, the psychosocial factors contributing to the development of the disease were evaluated together with the results of the studies in the literature. Research findings show that negative life events and psychological reasons are quite effective in the development of mental illnesses. In order to prevent the occurrence of psychiatric disorders or to be successful in treatment, the problems in this area should be resolved by considering psychosocial factors.
\end{abstract}

Key Words: Psychiatric disorder, Psychosocial Factor, Stress

${ }^{1}$ MSc., Psychology Department, Phd Student, Üsküdar University, İstanbul-Turkey,Orcid İd: https://orcid.org/ 0000-0001$8688-5564$

1 Prof. Dr., Psychology Department, Institute of Social Sciences, Üsküdar University, İstanbul-Turkey; Orcid İd: https://orcid.org/ 0000-0002-2514-5682

Address of Correspondence/Yazışma Adresi: Psychology Department, Phd Student, Üsküdar University, İstanbul-Turkey, E-mail: muneaktay@gmail.com

Date of Received/Geliş Tarihi: 22.06.2020, Date of Revision/Düzeltme Tarihi: 22.11.2020, Date of Acceptance/Kabul Tarihi: 20.02.2021, Date of Online Publication/Çevirimiçi Yayın Tarihi: 01.03.2021

Citing/Referans Gösterimi: Aktay, M., Sayar Hızlı, G. (2021). Psychosocial Aspect of Psychiatric Disorders., Cyprus Turkish Journal of Psychiatry \& Psychology, 3(1): 48-55

(C) 2020 The Author(s). Published by Cyprus Mental Health Institute / Cyprus Turkish Journal of Psychiatry and Psychology (www.ktppdergisi.com). This article is an open access article distributed under the terms and conditions of the Creative Commons Attribution 4.0 license which permits use, sharing, adaptation, distribution and reproduction in any medium or format, provided the original work is properly cited and is not used for commercial purposes. http://creativecommons.org/licenses/by/4.0/ 


\section{Öz:}

Psikiyatrik bozukluklar biyolojik, genetik, psikolojik ve çevresel faktörlerin bir araya gelmesi ve karşıllklı etkileşimleri sonucunda ortaya çıkmaktadır. Hastalıkların oluşumunda etkili olan faktörlerin belirlenmesi ve değerlendirilmesi tedavi açısından önem taşımaktadır. Stresli yaşam olayları, çocukluk çağı travmaları, aile içi sorunlar, çatışmalar ve kayıplar ruhsal hastalıkların başlamasında etkisi olan önemli psikososyal faktörlerdir. Bu çalışmada psikiyatrik bozuklukların ortaya çıkmasında önemli bir role sahip olan psikososyal etkenler incelenmektedir. Psikiyatrik bozuklukların tanımlamaları yapılarak hastalığın oluşmasında hangi psikososyal faktörlerin payı olduğu literatürdeki çalışmaların sonuçları ile birlikte değerlendirilmişstir. Araştırma bulguları olumsuz yaşam olaylarının ve psikolojik nedenlerin ruhsal hastalıkların gelişiminde oldukça etkili olduğunu göstermektedir. Psikiyatrik bozuklukların oluşmasının önlemesi veya tedavinin başarılı olması için psikososyal faktörler dikkate alınarak bu alandaki problemler çözüme kavuşturulmalıdır.

Anahtar Kelimeler: Psikiyatrik bozukluk, Psikososyal Faktör, Stres

\section{Giriş}

Psikiyatrik bozukluklar son yıllarda oldukça sık görülen, halk sağlığı açısından önemli sorunlarıdır. Bu rahatsızlıkların ortaya çıkmasında etkili olan faktörler hastalığın gelişimi açısından önemli bir konudur. Psikiyatrik bozuklukların etiyolojisi genetik, biyolojik, psikolojik, davranışsal, bilişsel ve çevresel faktörlere dayanmaktadır.

Yapılan çalışmalar olumsuz yaşantıların ve travmaların ruhsal bozukların gelişim sürecinde önemli etkisinin olduğunu göstermektedir. Biyolojik ve genetik etmenlerin çevresel risk faktörleriyle bir araya gelmesiyle psikiyatrik bozukluklar ortaya çıkmaktadır (Akbey, 2012; İngeç, 2018).

Yapılan çalışmalar psikiyatrik hastalıklarda bağlanma, ana-baba tutumları, aile içindeki iletişim ve ihmal gibi faktörlerin etkili olduğunu göstermektedir. Özellikle depresyon ve kaygı bozukluklarının gelişmesinde bağlanma stillerinin önemli bir payı olduğu çalışmalarda görülmüştür (Hamarta, 2004; Çelebi, 2017).

Çocukluk çağı travmaları ve olumsuz yaşantılar psikiyatrik bozukluklar için ciddi bir risk faktörü olarak görülmektedir. Bu konuda yapılan çalışmalarda psikiyatri hastalarında çocukluk çağı travmalarının oldukça sık olduğu görülmüştür. Fiziksel, cinsel ve duygusal ihmal ve istismarın psikiyatrik hastalıkların gelişmesinde etkili olduğu belirtilmektedir (Örsel, Karadağ, Kahiloğulları ve Aktaş, 2011). Literatürdeki pek çok çalışma ailesel faktörlerin, olumsuz yaşantıların ve özellikle çocukluk dönemi travmalarının kişiler üzerinde ciddi etkiler bıraktığını göstermektedir.

Psikiyatrik bozukluklar kişilerin günlük yaşamını, iş ve sosyal hayatını olumsuz yönde etkilemektedir. Kişiler günlük yaşantılarında görevlerini yerine getirmede, ihtiyaçlarını karşılamada ve sosyal ilişkilerini sürdürmede problemler yaşayabilmektedir. Ayrıca psikiyatrik hastalığı olan kişilere karşı toplum tarafindan olumsuz tutumların olduğu görülmektedir.

Özellikle damgalanma psikiyatrik bozukluğu olan hastaların karşılaştı̆̆ en büyük problemlerden biridir. Kişilerin sosyal hayatlarına uyum sağlayabilmeleri, yaşadıkları sorunların azalması ve işlev kayıplarının ilerlemesini durdurmak için tedavi gerekli görülmektedir. Tedavilerle birlikte psikiyatrik bozukluğun ilerlemesi ve riskli davranışların ortaya çıkması önlenmektedir. Psikiyatrik hastalıkların başlama nedenlerinin ve temellerinin duygu, düşünce ve davranışsal süreçleri nasıl etkilediğinin bilinmesi uygulanacak tedavilerde yardımc1 olmaktadır (Gerrig ve Zimbardo, 2017). Duygu, düşünce ve davranışlarımız birçok faktörden etkilenmektedir. Olumsuz yaşam deneyimleri, çocukluk çağı travmaları, aile içi sorunlar, iş hayatındaki problemler, çevresel koşullar, göç ve kayıp gibi durumlar hastalıkların oluşumu açısından önemli risk faktörleridir.

Psikososyal risk faktörleri psikiyatrik bozuklukların gelişmesinde ve ilerlemesinde önemli olan unsurlardandır. $\mathrm{Bu}$ risk faktörlerinin belirlenmesi, tedavi sürecinin yapılandırılması ve yürütülmesinde psikiyatrist ve psikologlara yardımcı olmaktadır. Bu doğrultuda bu çalışmada ruhsal bozuklukların gelişmesinde biyolojik unsurlar kadar psikososyal faktörlerin de önemli bir payının olduğunu yapılmış çalışmaların sonuçlarıyla birlikte göstererek bir derleme hazırlamak amaçlanmaktadır. Yaptığımız çalışma ile birlikte tüm psikiyatrik rahatsızlıkların oluşumunda hangi psikososyal faktörlerin etkili olduğuna ve bunlara neden önem verilmesi gerektiğine açıklık getirilmektedir.

Daha önceki çalışmalarda psikiyatrik bozuklukların hem biyolojik hem de sosyal nedenleri incelenmiştir. Fakat tüm psikiyatrik hastalıkların psikososyal nedenlerinin bir arada incelendiği ve değerlendirildiği bir çalışma yapılmamıştır. $\mathrm{Bu}$ açıdan psikiyatri ve psikoloji alanı için kapsamlı ve yardımcı bir çalışma olacağı düşünülmektedir. Çalışmada psikiyatrik bozuklukların DSM-V (Diagnostic and Statistical Manual of Mental Disorders) tan1 sinıflandırmasına göre tanımlamaları yapılarak oluşumunda etkili olan psikososyal faktörler değerlendirilecektir.

\section{Duygudurum Bozukluklarının Psikososyal Yönü}

Duygudurum bozukluklarında genellikle iki duygu durum ön plana çıkmaktadır. Yoğun ve gerçek dışı heyecan ve öfori duygularının görüldüğg̈ mani; üzüntü ve keder duygularının görüldüğ̈̈̈ depresyon temel duygudurumlardır (Butcher, Mineka ve Hooley, 2013). DSM-V'te duygudurum bozuklukları 'Çökkünlük 
Bozuklukları' ve ‘'̇ki Uçlu ve İlişkili Bozukluklar' olarak iki ayrı tanı grubuna ayrılmıştır (Amerikan Psikiyatri Birliği [APA], 2013).

Çökkünlük bozuklukları yani depresyon; üzüntülü ve bunalt1lı duygudurum ile birlikte düşünce, konuşma ve fizyolojik işlevlerde azalma, yavaşlama ve bunların yanı sıra değersizlik, isteksizlik, zevk alamama ve karamsarlık duygu ve düşüncelerinin olduğu bir sendromdur (Öztürk ve Uluşahin, 2018). Duygudurum bozukluklarında özellikle depresyonun gelişmesinde toplumsal faktörlerin etkisi oldukça fazladır. Aile ve iş hayatındaki sorunlar, ekonomik problemler, yaşanan kayıplar, çatışmalar ve travmatik olaylar depresyonun önemli yordayıcılarındandır. Yaşam olayları ve çevresel stresin depresyonda birincil role sahip olduğu düşünülmektedir. İşsizlik depresyonda etkili olan risk etmenlerinden biri olarak görülmektedir. Çalışmayan kişilerde çalışan kişilere oranla majör depresyon belirtileri üç kat fazla bildirilmektedir (Sadock, Sadock ve Ruiz, 2016). Depresyonun ortaya çımasında etkili olan stresli olayların çoğu, sevilen, değer verilen birinin kaybedilmesi, kişisel ilişkilere ya da kişinin mesleğine yönelik önemli tehditler, ekonomik problemler ya da önemli sağlık sorunları ile ilgilidir (Monroe ve Hadjiyannakis, 2002).

İki uçlu bozukluk yani bipolar bozukluk; iki ayrı hastalık dönemiyle karakterize bir duygudurum bozukluğudur. Erken çocukluk dönemindeki olumsuz yaşam olayları ve çevresel etmenler de bipolar bozukluğun ortaya çıkmasında önemli bir risk faktörü olarak görülmektedir. Psikososyal faktörler hastalığın gelişmesinde genetik faktörlerle beraber etkili olduğu düşünülmektedir. Çocukluk döneminde yaşanan travmatik olaylar hastalığın erken başlangıç göstermesine neden olmaktadır (Kesebir, İnanç, Bezgin ve Cengiz, 2013). Bipolar I ve Bipolar II bozuklukta çocukluk çağı travmalarının bilişsel işlevler ve duygusal zeka üzerindeki etkisini inceleyen bir çalışmada çocukluk çağı travmalarına maruziyetin bilişsel işlevlerdeki bozulma üzerine yordayıcı etkisinin olduğu görülmüştür. Ayrıca araştırmada çocukluk dönemindeki travmaların dikkat işlevlerini olumsuz yönde etkilediği saptanmıştır (Yıldız, 2020).

\section{Şizofreni Spektrumu ve Psikozla Giden Diğer Bozuklukların Psikososyal Yönü}

Şizofreni ve diğer psikotik bozukluklar duygu, düşünce ve davranışlarda ciddi bozulmaların görüldüğü, halüsinasyon ve hezeyanların olduğu, kişilerin günlük yaşantılarını derinden etkileyen rahatsızlıklardır (Yavuz, 2008). DSMV'te 'Şizofreni Açılımı Kapsamında ve Psikozla Giden Diğer Bozukluklar' olarak belirtilen bölümde; şizotipal kişilik bozukluğu, sanrılı bozukluk, kısa psikotik bozukluk, şizofreniform bozukluk, şizofreni ve şizoaffektif bozukluk tanı kategorileri yer almaktadır (APA, 2013).

Şizofreni, genellikle gençlik yıllarında başlayan, ruhsal durumun bütün alanlarında belirti ve bulgu gösteren ve kişide büyük ölçüde yeti yitimine sebep olan bir sağlık sorunudur (Soygür ve Erkoç, 2007). Şizofrenide risk faktörü olan kişilik yapısı ve hastalık öncesi dönemin özellikleri ile ilgili gerçekleştirilen bir çalışmada, şizofreni geliştiren kişilerde önemli olan değişkenlerin evde mutsuz hissetmek, işten veya okuldan memnuniyetsizlik, evden kaçmak, iş yaşantısında kötü muameleye maruz kalmak ve işten ayrılmak olduğu belirtilmiştir (Malmberg, Lewis, David ve Allebeck, 1998). Şizofreni ile sosyo-ekonomik düzey ve sosyal sınıf arasındaki ilişkinin incelendiği bir araştırmada babanın sosyal sınıfının düşük olması veya yoksul bir yerde doğmuş olması şizofreni riskini arttırdığ 1 saptanmıştır (Harrison, Gunnel, Glazebrook, Page ve Kwiecinski, 2001). Yapılan bir çalışmaya göre şizofreni hastalarında en çok görülen çocukluk çağı travması duygusal ihmaldir (İngeç, 2018).

Psikotik bozukluklarda etkili olduğu düşünülen en önemli psikososyal faktör maruz kalınan travmalardır. İsveç’te yapılan bir çalışmada düşük sosyo-ekonomik düzey, tek ebeveynli aile olma, kirada oturma, ebeveynin işsizliği ve sosyal yardım almanın şizofreni ve diğer psikotik bozukluk riskini artıran sosyal faktörler olduğu belirtilmiştir (Wicks, Hjern, Gunnel, Lewis ve Dalman, 2005).

\section{Kaygı (Anksiyete) Bozukluklarının Psikososyal Yönü}

Kaygı bozuklukları kişide yeti yitimine sebep olacak derecede endişe ve korkunun sürekli ve yoğun bir şekilde hissedilmesidir. DSM-V'te yer verilen kaygı bozuklukları; yaygın kaygı bozukluğu, panik bozukluk, fobik bozukluklar ve ayrılma kaygısı bozukluğu şeklindedir (APA, 2013).

Kaygı bozukluklarının ortaya çıkmasında ve gelişmesinde çevresel stres faktörlerinin ve travmatik yaşam öykülerinin etkisinin önemli olduğu düşünülmektedir. Panik bozukluk, yaşamı tehdit edebilecek herhangi bir tehlike unsuru yokken ortaya çıkan tekrarlayan panik atakların görüldüğü bir kaygı bozukluğudur (Güleç, 2009).

Panik bozukluğu olan kişilerin çocukluk çağı ihmal ve istismar yaşantıları yönünden incelendiği bir çalışmada panik bozukluk tanısı olan hastalarda çocukluk çağ kötüye kullanım yaşantısının yaygın olduğu görülmüştür. Hastaların \%66,7'sinde fiziksel ihmal, \%61,3'ünde duygusal ihmal yaşantısı saptanmıştır (Deniz, 2014).

Fobik bunaltı bozuklukları başlığı altında DSM-V'te sosyal fobi, agorafobi ve özgül fobiler yer almaktadır. Genel olarak fobi, normal de korkulmayacak belli bir durum veya nesne ile karşılaşıldığında kişide ortaya çıkan korkudur (Öztürk ve Uluşahin, 2018).

Fobiler genetik yatkınlıkla çevresel stres etkenleri arasındaki etkileşimi göstermektedir. Sosyal fobinin gelişmesinde ebeveynlerin çocuk yetiştirme tutumları, erken dönemdeki olumsuz yaşantılar, arkadaş ve kardeş ilişkileri etkili olabilecek faktörlerdir (Caster, Inderbitzen ve Hope, 1999).

Horney'e göre kaygı bozuklukları ebeveyn ve çocuk arasındaki olumsuz ilişkilerden kaynaklanmaktadır (Horney, 1991). Yapılan bir çalışmada ebeveynlerinden hayvanlar hakkında olumsuz ve tehdit edici bilgi alan çocukların hayvana karşı duydukları korkunun yüksek olduğu saptanmıştır (Muris, Van Zwol, Huijding ve Mayer, 2010).

DSM-V'te ayrılma kaygı bozukluğunun bir yaşam stresine bağlı olarak gelişebileceği belirtilmektedir. Okul değişimi, ebeveynlerin boşanması, taşınma ve göç gibi durumlar ayrılma kaygı bozukluğunun ortaya çıkmasında etkili olabilecek çevresel olaylardır (Özer, 2018).

Obsesif-Kompulsif Bozukluk ve İlişkili Bozuklukların Psikososyal Yönü 
Obsesif kompulsif bozukluk (OKB), obsesyon ve kompulsiyonlarla karakterize bir bozukluktur. Obsesyon kişinin kontrol edemediği tekrarlayan, mantıksız olmasına rağmen zihninden uzaklaştıramadığı düşünce, duygu, fikir ve dürtüleri ifade etmektedir. $\mathrm{Bu}$ istenmeyen saplantıl1 düşüncelerden kurtulmak için kişinin başvurduğu törensel tutum ve davranışlar kompulsiyonu oluşturmaktadır (Güleç, 2009). Obsesif-kompulsif bozukluk DSM-V'te 'saplantı-zorlantı bozukluğu' olarak isimlendirilmiştir. 'Saplantı-Zorlantı Bozukluğu ve İlişkili Bozukluklar' tanı başlığı altında beden dismorfik bozukluğu, biriktiricilik bozukluğu, kil yolma (trikotilomani) ve deri yolma bozukluğu yer almaktadır (APA, 2013).

Obsesif kompulsif bozukluğunun oluşmasında psikososyal faktörlerin oldukça etkili olduğunu gösteren çalışmalar yapılmıştır. Çocukluk döneminde aşırı kuralcı ve disiplinci eğitim veren toplumlarda düzenli, titiz, zaman ve düzen kavramlarına dikkat eden kişiliklerin yetiştiği belirtilmektedir. $\mathrm{Bu}$ durum toplumsal ve kültürel özelliklerin obsesif kompulsif belirtilerin șekillenmesinde önemli bir payının olduğunu göstermektedir. Özellikle dini inançlar belirtilerin şekillenmesinde etkili olmaktadır. Müslüman ülkelerde yapılan çalışmalarda obsesyonların daha çok dini temalı olduğu görülmüş̧ür (Öztürk ve Uluşahin, 2018; Veale, 2004a).

Obsesif Kompulsif Bozukluğu ve İlişkili Bozukluklar grubunda yer alan beden dismorfik bozukluğu, görünümde var olan küçük veya hayali bir kusur ile yoğun bir şekilde uğraşma ve kişide belirgin sıkıntıya yol açan bir bozukluktur (Altıntaş, 2015).

Beden dismorfik bozukluğunun oluşmasında sosyokültürel ve biyolojik nedenlerin etkili olduğu düşünülmektedir. Son zamanlarda ön planda olan güzellik algısı kişilerin bedenleriyle daha çok ilgilenmesine ve bu konuda kaygı yaşamalarına sebep olmaktadır.

Toplumda var olan güzellikle ilgili kalıplaşmış değer yargıları beden dismorfik bozukluğunun oluşmasında etkili olabilmektedir. Kişilerin dış görünüşlerinden dolayı olumsuz yönde eleştirilmesi kişide kayg1 yaratabilmektedir. Çocukluk döneminde alay edilen, çocukluk veya ergenlik döneminde şiddet ve zorbalığa maruz kalmak beden dismorfik bozukluğu oluşumunda önemli bir risk faktörüdür (Veale, 2004b).

OKB ile ilişkili bozukluklarda yer alan biriktiricilik, trikotillomani ve deri yolma bozukluğunun oluşmasında sosyal ve psikolojik faktörlerin rol oynadığı belirtilmektedir.

Biriktiricilik bozukluğuna sahip kişiler hastalık başlamadan önce veya hastalık sırasında belirtilerin stresli bir olay ya da travmatik bir olay sonrasında ortaya çıktığını belirtmektedir. Anne-çocuk ilişkisinde var olan problemler, yalnız bırakılma korkusu, yakın zamanda nesne kaybının yaşanması gibi faktörlerin saç yolma bozukluğunun gelişmesine yol açtığ 1 bildirilmektedir (Sadock ve ark., 2016).

Biriktiricilik, trikotillomani ve deri yolma bozukluklarının oluşmasının temelinde hangi psikososyal faktörlerin yattığına dair son yıllarda yapılan çalışmalarda pek değinilmemiştir.

Travma (Örselenme) ve Stresörle (Tetikleyici Etkenle) İlişkili Bozuklukların Psikososyal Yönü
Travma, kişileri hem ruhsal hem bedensel olarak derinden sarsan, günlük yaşantısını önemli ölçüde etkileyen olaylardır. DSM-V'te travma, gerçek bir ölüm veya ölüm tehdidi ve yaralanma gibi durumları içermektedir. DSMV'e göre Travma ve stresörle ilişkili bozukluklar tanı kategorisinde travma sonrasi stres bozukluğu, akut stres bozukluğu, tepkisel bağlanma bozukluğu, sınırsız toplumsal katılım bozukluğu ve uyum bozukluğu bulunmaktadır.

Travma sonrası stres bozukluğu (TSSB), ağır bir travmatik olay sonrasında ortaya çıkan, travmatik olayın tekrar tekrar yaşanmas1, olayı anımsatan uyaranlardan ve durumlardan kaçınma gibi belirtilerle karakterize bir bozukluktur. TSSB'nun ortaya çıkmasında birden fazla faktörün etkili olduğu düşünülmektedir. Etnik, kültürel, psikolojik, ailesel ve sosyal faktörler hastalığın gelişmesinde rol oynamaktadır. Kişinin yaşı, kişilik yapısı, geçirilmiş psikiyatrik bozukluk, genetik yatkınlık ve sosyal destek travma sonrası stres bozukluk için önemli olan faktörlerdir (Özgen ve Aydın, 1999; Doruk, 1998).

Travma sonrası stres bozukluğunun risk faktörleri ile ilgili yapılan bir meta-analiz çalışmasında maruz kalınan travmanın şiddeti, sosyal desteğin az olması ve diğer yaşam stresörleri TSSB'de etkili olan en güçlü faktörler olarak saptanmıştır (Brewin, Andrews ve Valentine, 2000).

Travma ve stresörle ilişkili bozukluklarda yer alan uyum bozukluğu, stresli veya olumsuz bir yaşam olayı sonrasında uyumsuz ve sağlıksız tepkilerden kaynaklanan bir bozukluktur (Çelik ve Özdemir, 2015). Uyum bozukluğu birçok stres faktörü tarafından tetiklenmektedir. Genellikle günlük hayatta karşılaşılan sevilen kişilerden ayrılma, ekonomik problemler, iş ve çevre değişikliği uyum bozukluğuna neden olan faktörlerdir (Newcorn, Strain ve Mezzich, 2000).

\section{Dissosiyatif Bozuklukların Psikososyal Yönü}

Disosiyatif bozukluklar bellek, alg1, kimlik, bilinç, motor davranışlar ve bilişsel işlevlerde bozulmaların yaşandığ rahatsızlıklardır (Butcher ve ark., 2013). DSM-V'te dissosiyatif bozukluklar 4 ana başlık altında incelenmektedir. Dissosiyatif kimlik bozukluğu, dissosiyatif amnezi, depersonalizasyon-derealizasyon bozukluğu ve tanımlanmamış dissosiyatif bozukluklar bu başlık altında incelenen bozukluklardır (APA, 2013).

Dissosiyatif bozukluklar, psikiyatrik hastalıklar arasında etiyolojik olarak çevresel faktörlerle en fazla ilişkisi olan bozukluklardan biridir. Çocukluk dönemi travmalarının en yoğun olduğu tanı grubu dissosiyatif bozukluklardır (Şar, 2017).

Yapılan bir çalışmada, dissosiyatif bozukluğu olan hastalarda cinsel ve duygusal istismar öyküsü saptanmıştır (İslam, 2009). Dissosiyatif kimlik bozukluğu çoğunlukla çocukluk çağı olumsuz yaşantıları ve çocukluk döneminde maruz kalınan ihmal ve istismarla ilişkili olmaktadır (Öztürk ve Şar, 2006). Çoğu dissosiyatif kimlik bozukluğu vakasında çocukluk döneminde invazif, korkutucu ve acı verici tıbbi müdahalelere maruz kalma öyküsüne rastlanmaktadır (Şar, 2017).

Disosiyatif amnezinin gelişmesinde psikososyal ortam önemli bir paya sahiptir. Amnezi çoğunlukla ağır bir psikososyal stres anında ortaya çıkmaktadır. Bir tehdit anında çıkmaza düşme, değer verilen bir şeyin 
kaybedilmesi veya kaybetme olasılığının olması, baş edilemeyen ve kişide panik oluşturan eğilimler hissetme gibi durumlar genellikle hastalığın başlamasında etken olarak görülmektedir.

Savaş ve doğal afetler zamanında çoğunlukla amneziye füg eşlik etmektedir. Kişisel reddedilme, evlilik problemleri, ekonomik sıkıntılar ve kayılar dissosiyatif amnezi vakalarının ortaya çıkmasında rol oynayan faktörlerdir. Depersonalizasyon ve derealizasyon bozukluğu yaşamı tehdit eden durumlarda ve yoğun stres anında geçici olarak ortaya çıkabilir (Şar, 2017).

\section{Yeme Bozukluklarının Psikososyal Yönü}

Yeme bozuklukları, aşırı yeme veya yetersiz beslenme ile karakterize yeme davranışının ciddi anlamda bozulduğu durumları ifade etmektedir. DSM-V siniflandırmasında yeme bozuklukları; pika, geri çıkarma (geviş getirme) bozukluğu, kaçıngan/kısıtlı yiyecek alımı bozukluğu, anoreksiya nervoza, bulimiya nervoza ve tıkınırcasına yeme bozukluğunu içermektedir (APA, 2013).

Yeme bozukluğunun ortaya çıkmasında psikososyal faktörler etkili bir rol oynamaktadır. Aile işlevselliği, düşük benlik saygısı, ailede yeme bozukluğu öyküsü, duygudurum bozuklukları, madde kötüye kullanımı, OKB, olumsuz yaşam deneyimleri ve ergenlik sorunlarının yeme bozukluklarının ortaya çıkmasında etkili olduğu düşünülmektedir (Fairburn, Cooper, Doll ve Welch, 1999).

Aile ortamının ve aile işlevselliğinin değerlendirildiği bir çalışmada, yeme bozukluğu olan hastaların aile işlevselliği ve yetiştirilme tarzlarını sağlıklı kontrollere göre daha olumsuz algıladığı saptanmıştır. Hastaların kontrollere göre beden imajlarının daha bozuk, benlik saygısı düzeylerinin daha düşük ve aleksitimi düzeylerinin daha yüksek olduğu görülmüştür (Ertekin, 2010).

Kilo ile dalga geçilmesi, dış görünüşle ilgili karşılaştırmaların yapılması, yakın çevre tarafından olumsuz eleştirilerin yapılması ve zayıf olmanın çekiciliği yeme bozukluğunun gelişmesinde etkili olmaktadır (Sinton ve ark., 2012). Aşırı müdahaleci, koruyucu, bireyselleşmeye izin vermeyen aile yapısı ve mükemmeliyetçilik yeme bozukluklarının oluşmasında önemli yeri olan faktörler arasında görülmektedir (Yücel, 2019).

Çocukluk çağında cinsel ve fiziksel istismara maruz kalma, hastalık başlamadan önceki dönemde kaygı ve duygudurum bozuklukları, ebeveynin aşırı ya da yetersiz düzeyde müdahalede bulunması hastalığın oluşmasında etkili olan faktörlerdir (Yücel, 2009).

Çocukluk döneminde olumsuz yaşantılar, ebeveyn depresyonu, beden ve görünümüme ilişkin olumsuz yorumlara maruz kalma ve özgüven eksikliğinin tıkınırcasına yeme bozukluğunun gelişmesinde önemli risk faktörleri olduğu yapılan çalışmalarda ortaya çıkmıştır (Fairburn ve ark., 1998).

\section{Uyku-Uyanıklık Bozukluklarının Psikososyal Yönü}

Uyku, bazı temel mekanizmalar tarafindan düzenlenir ve bu mekanizmalar ters gittiğinde uyku bozuklukları ortaya çıkmaktadır. Uyku bozuklukları kişilerin yaşam kalitesini düşüren uykusuzluk veya aşırı uykuyla karakterize bozukluklardır (Sadock ve ark., 2016). DSM-V'te uyku- uyanıklık bozuklukları başlığı altında insomnia, hipersomnia, narkolepsi, solunumla ilişkili uyku bozuklukları, sirkadiyen ritim uyku uyanıklık bozuklukları, parasomnialar, huzursuz bacak sendromu, madde/ilacın yol açtığı uyku bozukluğu, tanımlanmış diğer ve tanımlanmamış diğer uyku bozukluğu ele alınmıştır (APA, 2013).

Kısa süreli uykusuzluklar genellikle anksiyete ile ilişkilendirilmektedir. Bazı insanlarda uykusuzluk üzüntü, kayıp veya stresli olaylar ile ilişkili olabilmektedir. Sürekli uykusuzluk fiziksel gerginlik, kaygı ve şartlı bir tepki gibi birtakım sorunlarla bağlantılı olarak ortaya çıabilmektedir (Sadock ve ark., 2016). Son zamanlarda yapılan çalışmalarda uyku-uyanıklık bozukluklarının ortaya çıkmasında etkili olan psikososyal nedenlerle ilgili bilgilere pek yer verilmediği görülmektedir.

\section{Cinsel İşlev Bozukluklarının Psikososyal Yönü}

Cinsel işlev bozukluklarının temel özelliği; cinsel uyarıma cevap vermede yetersizliğin olması veya cinsel ilişki esnasında ağrı deneyiminin olmasıdır. DSM-V'te cinsel işlev bozuklukları başlığı altında; geç boşalma, sertleşme bozukluğu, kadında orgazm bozukluğu, kadında cinsel ilgi/uyarılma bozukluğu, cinsel organlarda-pelviste ağrı/içe girme bozukluğu, erkekte düşük cinsel istek bozukluğu ve erken boşalma incelenmektedir (APA, 2013).

Cinsel problemlerin hem biyolojik hem de psikolojik kaynaklı olduğu belirtilmektedir. Psikiyatri polikliniğine başvuran kadın hastalarda cinsel işlev bozukluğu ve ilişkili sosyokültürel parametrelerin değerlendirildiği bir çalışmada, sosyokültürel yapının cinsel yaşamı olumsuz yönde etkilediği saptanmıştır. Kişinin evlenme şekli, ilk cinsel bilgileri öğrenme şekli ve ailelerin cinselliğe karşı tutumunun cinsel işlev bozukluğunun oluşmasında etkili olan sosyokültürel faktörlerdir (Mert ve Özen, 2011).

Cinsel problemler; yetiştirilme tarzı, cinsel dürtünün düşüklüğü, cinsel bilgi eksikliği veya yanlışlığı, cinsel deneyim eksikliği, eşle olan genel ilişkinin zayıflığ 1 ve cinsel performansa ilişkin kaygı nedeniyle ortaya çıkmaktadır. Ayrıca, terkedilme korkusu, çözülmemiş ödipal sorun, evlilikle ilgili kızgınlıklar, cinsellikle ilgili ahlaki ve dini suçluluk duyguları gerilimli bir cinsel ortam yaratarak cinsel aksamalara sebep olmaktadır (Kayır, 2009). Çocukluk ve ergenlik dönemine ait psikoseksüel gelişim dönemindeki aksaklıklar, yanlış öğrenilmiş cinsel davranışlar, yetersiz cinsel bilgi, geleneksel ve tutucu yetiştirilme, utanma, suçluluk ve günahkarlık duyguları cinsel problemlerin oluşmasında etkili olan faktörlerdir (İncesu, 2004).

\section{Yıkıcı Bozukluklar, Dürtü-Kontrol ve Davranım Bozukluklarının Psikososyal Yönü}

Dürtü kontrol bozuklukları, kişinin kendisine veya başkalarına zarar verebilecek davranışları gerçekleştirme istek ve arzularına yineleyici bir şekilde karşı koyamama ile karakterize bir bozukluktur. Y1kıcı davranım bozuklukları ise agresyon ve kurallara karşı gelme ile karakterizedir (Tamam ve Döngel, 2018; APA, 2013). DSM-V'te yıkıcı bozukluklar, dürtü kontrol ve davranım bozuklukları kategorisinde yer alan bozukluklar; karşıt olma karşıt gelme bozukluğu, aralıklı patlayıcı bozukluk, davranım bozukluğu, piromani ve kleptomanidir. 
Dürtü kontrol bozukluklarının gelişmesinde rol oynayan psikososyal faktörler, erken yaşam olayları ile ilişkili olmaktadır. Dürtülerini kontrol etmede zorluk yaşayan ebeveynlere sahip olan çocuklarda dürtü kontrol bozukluğu gelişebilmektedir. Diğer psikososyal faktörler; evde şiddete maruz kalma, alkol ve madde kullanımı ve antisosyal davranışlardır (Sadock ve ark., 2016).

Karşıt olma karşıt gelme bozukluğu olan çocukların ebeveynlerine güvensiz bağlanma geliştirdikleri yapılan araştırmalarda belirlenmiştir. Ebeveynlerin ilgisizliği, aile içi bağların zayıf olması, aile içi şiddet, çocuk ihmal ve istismarı gibi olumsuz yaşam olayları bozukluğun ortaya çıkmasında etkili olmaktadır (Tamam ve Döngel, 2018).

Aralıklı patlayıcı bozukluğun etiyolojisinde biyolojik nedenlerin yanı sıra çocukluk travmaları gibi psikososyal nedenlerin de rol oynadığ 1 belirtilmektedir (Tamam, Eroğlu ve Paltacı, 2011).

Fiziksel ve cinsel istismar öyküsü, madde kullanımı ve bozuk aile yapısı piromani için risk faktörü olarak görülmektedir (Tamam ve Döngel, 2018). Piromani ve kleptomaninin psikososyal yönleri ile ilgili bilgilere yakın zamanda yapılmış çalışmalarda yer verilmediği görülmektedir.

Davranım bozukluğunun gelișmesinde ebeveyn davranıșı ve aile faktörü önemli yer tutmaktadır. Ebeveynlerin tutarsızlığı, çocuklarına şiddet içerikli ceza uygulamaları ve çocuklarını denetimdeki zayıflıklar çocukluk çağındaki davranım sorunlarını olumsuz yönde etkilemektedir (Burke, Pardini ve Loeber, 2008). Çocuğun yetiştirilirken hiç engellenmeyle karşılaşmaması veya aşırı düzeyde cezalandırılması davranım bozukluğuna yol açan önemli faktörlerdir. (Tamam ve Döngel, 2018).

\section{Madde ile İlişkili Bozuklukların Psikososyal Yönü}

Madde kullanım bozukluğu maddenin uzun süre kullanımından dolayı nedensiz olarak maddenin kötüye kullanımını ifade etmektedir (Sadock ve ark., 2016). Madde ile ilişkili bozukluklar DSM-V'te madde kullanım bozuklukları ve madde kullanımının yol açtı̆̆ bozukluklar olmak üzere iki grupta incelenmektedir (APA, 2013).

Madde kullanım bozukluğu, kişinin madde ile ilişkili problemler yaşamasına rağmen madde kullanımına devam ettiği bir bozukluktur. Madde kullanımının yol açtığ 1 bozukluklar ise madde kullanımı sonucunda psikotik bozuklukların gelişmesi durumudur (Karaoğlan, Kaşarc1, Şahin ve İplik, 2020).

Madde kullanım bozukluklarının gelişmesinde çevresel faktörlerin etkili bir rol oynadığı belirtilmektedir. Özellikle aile koşulları önemli bir risk faktörü olabilmektedir. Aile ilişkilerinin çatışmalı olması, çocuğa ya da gence ayrılan zamanın nicelik ve nitelik bakımından yetersiz olmas1, ebeveynlerin gözetimi ve dikkatinin az olması madde kullanım bozukluğu için yordayıcı faktörlerdir.

Maddenin kolay elde edilebilirliği, arkadaş grupları ve madde kullanımının prestij ve üstünlük sağladığ 1 topluluklar da madde kullanım bozukluğunun başlamasında etkili olmaktadır (Uluğ ve Öztürk, 2018). Aile içindeki ilişkiler ve anne babanın çocuğu yönlendirme şekli çocuğun gelişiminde oldukça etkilidir. Ergenler genellikle alkole ya da maddeye akranları arasındaki popülerlik veya kabullenirliğin artması beklentisiyle başlamaktadır (Butcher ve ark., 2013).

Madde kullanım bozukluğu olan ergenlerde çocukluk çağı travmalarının bağlanma ile ilişkisinin incelendiği bir çalışmada madde kullanım sıklığı olan ergenlerde çocukluk çağı travması yüksek bulunmuştur (Balc1, 2011). Kumar oynama bozukluğunun gelişmesinde ergenlik döneminde ebeveyn kaybı, ayrılık veya terk edilme, olumsuz ebeveyn davranıșları ve bu dönemde kumar aktivitelerine maruz kalma etkili olmaktadır (Sadock ve ark., 2016).

\section{Kişilik Bozukluklarının Psikososyal Yönü}

Kişilik bozuklukları, kişinin kendi kültürüne göre, beklenenden önemli ölçüde sapmaların olduğu, süreklilik gösteren bir iç yaşantılar ve davranışlar örüntüsüdür. DSM-V'te kişilik bozuklukları üç ana kümede sınıflandırılmaktadır. A kümesi; paranoid, şizoid ve şizotipal kişilik bozukluğunu içermektedir. B kümesinde; antisosyal, sinırda (borderline), histrionik ve narsistik kişilik bozukluğu bulunmaktadır. C küme kişilik bozukluklarında ise; kaçıngan, bağımlı ve obsesifkompulsif kişilik bozukluğu yer almaktadır (APA, 2013).

Kişilik bozukluklarının, birçok faktörün karşılıklı etkileşimleri ve bir araya gelmeleri ile geliştiği belirtilmektedir. Erken çocukluk dönemlerindeki anne baba ilișkileri kișilik bozukluklarında önemli bir yer tutmaktadır. Kişinin kendisini ve diğerlerini algılamasındaki problemler kişilik bozukluklarının temel problemi olmaktadır (Şahin, 2009).

Borderline kişilik bozukluğu tanısı alan hastalarda çocukluk çağı travmatik yaşantıları ve bağlanma biçimleri ile ilişkisinin araştırıldığı bir çalışmada, kişilik bozukluğu olan hastalarda sağlıklı gruba göre çocukluk çağı travması daha yüksek bulunmuştur (Parlar, 2019). Anne baba tarafindan ihmal edilmek veya kötü muameleye maruz kalmak, şiddet görmek kişilik bozukluklarının ortaya çıkmasında etkili olan psikososyal faktörlerden bazılarıdır.

Çocukluk döneminde yaşanan istismar ve travma kişilik bozukluklarının oluşmasında rol oynamaktadır. Kohut'a göre ebeveynlerin ihmalkâr olması, aşağılayııı ve empati kuramayan davranışlarda bulunması narsistik kişilik bozukluğuna eğilimi artırmaktadır.

Milon'a göre narsistik kişilik bozukluğu, ebeveynlerin gerçekçi olmayan aşırı değer biçmesinden kaynaklanmaktadır. Çocukluk döneminde yaşanan olumsuz olaylar ve travmalar kişilik bozukluklarında önemli psikososyal etkenlerdir. İstismar, ihmal, değer verilen kişilerin kaybı ve travmatik ayrılıklar bozukluklara yatkınlığı artıran faktörlerdir (Butcher ve ark., 2013).

\section{Sonuç}

Toplumda oldukça sık görülen psikiyatrik bozuklukların ortaya çıkış nedenlerinin belirlenmesi hem hastalığın gelişimi hem de tedavisi açısında önem taşımaktadır. Bu hastalıklarda etkisi olan birçok faktör bulunmaktadır. Genetik yatkınlıklarla birlikte psikososyal faktörlerin rolü oldukça büyüktür. Aile ve çevre koşulları, şiddet, ekonomik sorunlar, eğitim düzeyi, bağlanma ve travma gibi pek çok psikolojik ve sosyal nedenler psikiyatrik hastalıkların başlamasında etkili olduğu belirtilmektedir. $\mathrm{Bu}$ konuda yapılmış araştırmalar incelendiğinde özellikle 
çocukluk çağı travmalarının, aile içi şiddetin, ana-baba tutumunun, ihmal ve istismarın ruhsal hastalıkların gelişmesinde kritik bir önem taşıdığı görülmektedir.

Çocukluk dönemi yaşantıları ve aile koşulları hastalıklar için ciddi bir risk faktörü olmaktadır. $\mathrm{Bu}$ bağlamda psikiyatrik bozuklukların oluşmasını önlemek veya tedavi sürecinde başarılı olunması için çocukluk ve ergenlik dönemlerine daha fazla dikkat edilmelidir.

Yanlış ebeveyn davranışlarının ve sağlıksız ana-baba tutumlarının düzeltilmesi için çalışmalar yapılmalıdır. Psikiyatrik hastalıkların ortaya çıkmasında önemli payı olan çocukluk çağındaki ihmal ve istismar konusunda ve bunun önlenmesine yönelik projeler ve araştırmalar gerçekleştirilebilir.

\section{Beyannameler}

Etik Onay ve Katılma İzni

Uygulanamaz.

\section{Yayın İzni \\ Uygulanamaz.}

Veri ve Materyallerin Mevcudiyeti

Uygulanamaz. Çalışma alan yazının taranması ile oluşmuştur. Herhangi bir veri kullanılmamıştır.

\section{Çıkar Çatış̧asısı}

Uygulanamaz.

\section{Finansman}

Çalışmanın gerçekleştirilmesinde finansal destek alınmamıştır.

\section{Yazar Katkıları}

GHS çalışmanın ana fikir ve tasarımına önemli katkılar sağlamıştır.

MA literatürün taranması, çalışmaların incelenmesi ve makalenin yazılmasında katkı sağlamıştır. Tüm yazarlar makalenin son halini okumuş ve onaylamıştır.

\section{Teşekkür}

Uygulanamaz.

\section{Yazarlarm bilgileri}

Müne Aktay Üsküdar Üniversitesi Psikoloji Bölümü Doktora Öğrencisi

\section{Kaynaklar}

Altıntaş, E. (2015). Kozmetik tedavisi için başvuran hastalarda beden dismorfik bozukluğu. Arşiv Kaynak Tarama Dergisi, 24(3), 324-338.

Amerikan Psikiyatri Birliği, (2013). (DSM-V). Diagnostic and Statistical Manual of Mental Disorders (DSM-V). Ankara: Hekimler Yayın Birliği.

Balcı, G. (2011). Madde kullanım bozukluğu olan ergenlerde çocukluk çağı travmalarının bağlanma ile ilişskisi. (Tıpta Uzmanlık Tezi). Bakırköy Prof. Dr. Mazhar Osman Ruh Sağlı̆̆ı ve Sinir Hastalıkları Eğitim ve Araştırma Hastanesi Psikiyatri Birimi, İstanbul.

Burke, J. D., Pardini, D. A. ve Loeber, R. (2008). Reciprocal relationships between parenting behavior and disruptive psychopathology from childhood through adolescence. Journal of Abnormal Child Psychology, 36(5), 679-692.

Butcher, J. N., Mineka, S. ve Hooley, J. M. (2013). Anormal Psikoloji. İstanbul: Kaknüs Yayınları.

Brewin, C., Andrews, B. Ve Valentine, J. (2000). Meta-analysis of risk factors for posttraumatic stress disorder in trauma-exposed adults. Journal of Consulting and Clinical Psychology, 68(5), 748766.

Caster, J., Inderbitzen, H. ve Hope, D. (1999). Relationship between youth and parent perceptions of family environment and social anxiety. Journal of Anxiety Disorders, 13(3), 237-251.

Çelebi, G. (2017). Ergenlerde sosyal kaygı ve bağlanma stilleri arasındaki iliş̧inin incelenmesi. Kastamonu Eğitim Dergisi, 25(5), 1729-1736.

Çelik, C. ve Özdemir, B. (2015). Uyum bozukluğunun tedavisi. Türkiye Klinikleri Dergisi, 8(1), 61-67.

Deniz, İ. (2014). Panik bozukluk tanılı hastaların çocukluk çağı ihmal velveya istismar yașantılar yönünden incelenmesi. (Yayımlanmamış Yüksek Lisans Tezi). Haliç Üniversitesi Sağlık Bilimleri Enstitüsü, İstanbul.

Doruk, A. (1998). Travma sonrast stres bozukluğunda etyolojik faktörlerin araşstırılması. (Uzmanlık Tezi). Gülhane Askeri Tip Akademisi Askeri Tıp Akademisi Askeri Tıp Fakültesi, Ankara.

Ertekin, B. (2010). Yeme bozukluğu hastalarında aile ortaminın ve aile işlevselliğinin değerlendirilmesi. (Uzmanlık Tezi). İstanbul Üniversitesi Tip Fakültesi Psikiyatri Anabilim Dalı, İstanbul.
Fairburn, C. G., Doll, H. A., Welch, S. L., Hay, P. J., Davies, B. A. ve O'Connor, M. E. (1998). Risk factors for binge eating disorder: a community-based, case-control study. Archives of General Psychiatry, 55(5), 425-432.

Fairburn, C. G., Cooper, Z., Doll, H. A. ve Welch, S. L. (1999). Risk factors for anorexia nervosa: three integrated case-control comparisons. Archives of General Psychiatry, 56(5), 468-476.

Gerrig, R. J. ve Zimbardo, P G. (2017). Psikoloji ve Yaşam. İstanbul: Nobel Akademik Yayıncıllk.

Güleç, C. (2009). Psikiyatri’nin ABC'si. İstanbul: Say Yayınları.

Hamarta, E. (2004). Üniversite ögrencilerinin yakn ilişkilerindeki bazı değișkenlerin (benlik saygısı, depresyon ve saplantıl dü̈sünme) bağlanma stilleri açısından incelenmesi. (Doktora Tezi). Selçuk Üniversitesi Sosyal Bilimler Enstitüsü Eğitim Bilimleri Anabilim Dalı, Konya.

Harrison, G., Gunnel, D., Glazebrook, C., Page, K. ve Kwiecinski, R. (2001). Association between schizophrenia and social inequality at birth: case-control study. British Journal of Psychiatry, 179, 346-350.

Horney, K. (1991). Nevrozlar ve İnsan Gelişimi: Öz Gerçekleştirme Kavgası. Ankara: Öteki Yayınevi.

İncesu, C. (2004). Cinsel işlevler ve cinsel işlev bozuklukları. Klinik Psikiyatri, 3, 3-13.

İngeç, C. (2018). Şizofreni hastalarında çocukluk çă̆g travmasının şizofreni hastalık başlangıç yaşına etkisi. (Uzmanlık Tezi). İzmir Katip Çelebi Üniversitesi Atatürk Eğitim ve Araştırma Hastanesi Psikiyatri Kliniği, İzmir.

İslam, S. (2009). Karmaşı dissosiyatif bozukluk ve major depresyonun aleksitimi, bilişsel içgörü̈, kişilerarası bağlanma ve intihar eğilimi açısından karş̧laş̧ırılması. (Uzmanlık Tezi). İstanbul Üniversitesi Tıp Fakültesi Psikiyatri Anabilim Dalı, İstanbul.

Karaoğlan, M., Kaşarcı, G., Şahin, E. ve İplik, E. (2020). Madde ilişkili psikotik bozuklukların tedavisinde kullanılan atipik antipsikotikler. Experimed, 10(1), 49-58.

Kayır, A. (2009). Cinsellik ve Cinsel İşlev Bozuklukları. Adam, E., Tükel, R.M., Yazıcı, O. (Ed.) Psikiyatri. İstanbul: İstanbul Üniversitesi Basım ve Yayınevi. 
Kesebir, S., İnanç, L., Bezgin, C. ve Cengiz, F. (2013). Kadınlarda bipolar bozukluk. Psikiyatride Güncel Yaklaşımlar, 5(2), 220231.

Malmberg, A., Lewis, G., David, A. ve Allebeck, P. (1998). Premorbid adjustment and personality in people with schizophrenia. British Journal of Psychiatry, 172, 308-313.

Mert, D. ve Özen, N. (2011). Genel psikiyatri polikliniğine başvuran kadın hastalarda cinsel işlev bozukluğu ve ilişkili sosyokültürel parametrelerin değerlendirilmesi. Klinik Psikiyatri, 14, 85-93.

Monroe, S. M. ve Hadjiyannakis, K. (2002). The social environment and depression: Focusing on severe life stress. Handbook of Depression, 314-340.

Muris, P., Van Zwol, L., Huijding, J. ve Mayer, B. (2010). Mom told me scary things about this animal: parents installing fear beliefs in their children via the verbal information pathway. Behaviour Research and Therapy, 48(4), 341-346.

Newcorn, J N, Strain, J J. ve Mezzich, J E. (2000). Adjustment disorders. Philadelphia: Comprehensive Textbook of Psychiatry.

Örsel, S., Karadağ, H., Kahiloğulları, A. ve Aktaş, E. (2011). Psikiyatri hastalarında çocukluk çağı travmalarının siklığı ve psikopatoloji ile ilişkisi. Anadolu Psikiyatri Dergisi, 12, 130-136.

Özer, İ. (2018). Bağlanmanın doğal sonucu: Ayrılma kaygısı. ÇOMÜ Uluslararası Sosyal Bilimler Dergisi, 3(1), 125-134.

Özgen, F. ve Aydın, H. (1999). Travma sonrası stres bozukluğu. Klinik Psikiyatri, 1, 34-41.

Öztürk, E. ve Şar, V. (2006). The 'Apparently normal' family: A contemporary agent of transgenerational trauma and dissociation. Journal of Trauma Practice, 4(3-4), 287-303.

Öztürk, O. ve Uluşahin, A. (2018). Ruh Sağlığı ve Bozuklukları. Ankara: Nobel Tip Kitapevleri.

Parlar, Ö. (2019). Borderline kişilik bozukluğu tanısı alan hastalarda dürtüsellik ve dissosiyatif semptomların çocukluk çağ travmatik yaşantılar ve bağlanma biçimleri ile iliş̧kisinin araştırılması. (Tipta Uzmanlık Tezi). Sağlık Bilimleri Üniversitesi, İstanbul.

Sadock, B J., Sadock, V A. ve Ruiz, P. (2016). Psikiyatri. İstanbul: Güneş Tıp Kitabevleri.
Sinton, M., Goldschmidt, A., Aspen, V., Theim, K., Stein, R., Saelens, B., Epstein, L. Ve Wilfley, D. (2012). Psychosocial correlates of shape and weight concerns in overweight preadolescents. Journal of Youth and Adolescence, 41, 67-75.

Soygür, H. ve Erkoç, Ş. (2007). Şizofreni Kavramına Tarihsel Bir Bakış. Şizofreni ve Diğer Psikotik Bozukluklar. Ankara: Türkiye Psikiyatri Derneği Yayınları.

Şahin, D. (2009). Kişilik bozuklukları. Klinik Gelişiım, 22(4), 45 55.

Şar, V. (2017). Dissosiyatif Bozukluklar. Temel ve Klinik Psikiyatri. Ankara: Güneş Tıp Kitabevi.

Tamam, L., Eroğlu, M. ve Paltacı, Ö. (2011). Aralıklı patlayıcı bozukluk. Psikiyatride Güncel Yaklaşımlar, 3(3), 387-425.

Tamam, L. ve Döngel, B. (2018). Yıkıcı bozukluklar, dürtü kontrol ve davranım bozuklukları. Temel ve Klinik Psikiyatri. Ankara: Güneş Yayınevi.

Uluğ, B. ve Öztürk, O. (2018). Psikoaktif madde kullanıma bağlı rusal bozukluklar. Ruh Sağlığı ve Bozuklukları kitabı içinde. Ankara: Nobel Tip Kitapevleri.

Veale, D. (2004a). Psychopathology of obsessive-compulsive disorder. Psychiatry, 3(6), 65-68.

Veale, D. (2004b). Body dysmorphic disorder. Postgraduate Medical Journal, 80(940), 61-71.

Wicks, S., Hjern, A., Gunnel, D., Lewis, G. ve Dalman, C. (2005). Social adversity in childhood and risk developing psychosis: a national cohort study. The American Journal of Psychiatry, 162(9), 1652-1657.

Yavuz, R. (2008). Türkiye'de ssk karsslassılan psikiyatrik hastalıklar. Şizofreni. İ.Ü. Cerrahpaşa Tıp Fakültesi Sürekli Tıp Eğitimi Etkinlikleri, 62, 49-58.

Yıldız, S. (2020). Duygudurum bozukluklarında çocukluk çă̆ı travmalarının bilişsel işlevler üzerine etkisi. (Tıpta Uzmanlık Tezi). Eskișehir Osman Gazi Üniversitesi Tip Fakültesi, Eskişehir.

Yücel, B. (2009). Estetik bir kaygıdan hastalığa uzanan yol: Yeme bozuklukları. Klinik Gelișim, 22(4), 39-44. 